\title{
PENANAMAN NILAI KARAKTER MELALUI PEMBELAJARAN SASTRA DALAM MATA KULIAH BAHASA INDONESIA DI PERGURUAN TINGGI ${ }^{1}$
}

\author{
Sitti Rabiah ${ }^{2}$ \\ Program Studi Bahasa dan Sastra Indonesia \\ Fakultas Sastra, Universitas Muslim Indonesia
}

\begin{abstract}
Abstrak
Urgensi penanaman nilai-nilai karakter bagi mahasiswa sudah merupakan hal yang tidak bisa ditawar-tawar lagi. Realita kontras terlihat antara putra-putri Indonesia yang mengharumkan nama bangsa di kancah internasional, sedangkan masih ada mahasiswa yang terlibat sebagai pelaku tindak kejahatan dan kriminalitas cukup tinggi, seperti narkoba, dan seks bebas. Fenomena tersebut menuntut agar sistem pendidikan di kaji ulang. Salah satu upaya untuk menjawab persoalan tersebut yakni dengan mengintegrasikan pendidikan karakter dengan mata kuliah, dalam hal ini bahasa Indonesia. Melalui tulisan ini, penulis menindaklanjuti rekomendasi yang telah disampaikan pada Kongres Bahasa Indonesia X terkait pengembangan pembelajaran sastra dalam mata kuliah bahasa Indonesia di perguruan tinggi. Dalam hal ini, peneliti memandang bahwa pembelajaran sastra merupakan materi yang sangat kaya untuk pengembangan nilai-nilai karakter serta sangat variatif dalam mengeksplorasi cara pengajarannya kepada peserta didik. Peneliti menggunakan kajian teoretik untuk melihat kemungkinan direalisasikannya gagasan ini. Temuan dari penelitian ini adalah pembelajaran sastra dalam mata kuliah bahasa Indonesia di perguruan tinggi sangat realistis untuk diwujudkan. Hal ini didasarkan pada fleksibilitas pembelajaran sastra jika diintegrasikan dengan keterampilan berbahasa akan saling melengkapi.
\end{abstract}

Kata Kunci: Karakter, Pembelajaran Sastra, Bahasa Indonesia, Perguruan Tinggi

\section{Abstract}

The urgency of character building values for the student is already a thing that can't be negotiable. The contrast reality between the students from Indonesia that make our nation proud to them in the international arena, while there are students who are involved as perpetrators of crime and criminality is quite high, such as drugs, and free sex. This phenomenon requires that the education system in the review. One effort to address these issues is by integrating character education with subjects, in this case Indonesian language. Through this paper, the authors implementing the recommendations that have been presented at the Kongres Bahasa Indonesia $X$ related to the development of literature learning in Indonesian language course in higher education. In this case, the researcher believes that the literature learning is very rich to develop character values and the values are very varied in exploring ways of teaching to students. Researchers used a theoretical study to look at the possibility of the realization of this idea. The finding of this study is the literature learning in Indonesian language courses in higher education is very realistic to be realized. It is based on the flexibility of the literature learning when integrated with language skills will complementary each other.

Keywords: Character, Literature Learning, Indonesian Languages, Higher Education

\footnotetext{
${ }^{1}$ Makalah telah dipresentasikan dalam Pertemuan Ilmiah Bahasa dan Sastra Indonesia XXXVI yang diselenggarakan oleh Program Studi Pendidikan Bahasa dan Sastra Indonesia, FKIP, Universitas Ahmad Dahlan pada 11-12 Oktober 2014 di Yogyakarta.

2 (D) https:// orcid.org/ 0000-0002-1690-0025. Kontak penulis: sitti.rabiah@umi.ac.id / sittirabiah25@gmail.com
} 


\section{A. Pendahuluan}

Pemerintah melalui Undang-undang No. 20 Tahun 2003 tentang Sistem Pendidikan Nasional pada Pasal 3, menyebutkan bahwa pendidikan berfungsi mengembangkan kemampuan dan membentuk karakter serta peradaban bangsa yang bermartabat dalam rangka mencerdaskan kehidupan bangsa. Pendidikan nasional bertujuan untuk berkembangnya potensi peserta didik agar menjadi manusia yang beriman dan bertakwa kepada Tuhan Yang Maha Esa, berakhlak mulia, sehat, berilmu, cakap, kreatif, mandiri, dan menjadi warga negara yang demokratis serta bertanggungjawab.

Berdasarkan fungsi dan tujuan pendidikan nasional, jelas bahwa pendidikan di setiap jenjang, harus diselenggarakan secara sistematis guna mencapai tujuan tersebut. Hal tersebut berkaitan dengan pembentukan karakter peserta didik sehingga mampu bersaing, beretika, bermoral, sopan santun, dan berinteraksi dengan masyarakat.

Dalam konteks keindonesiaan, khususnya realitas di perguruan tinggi penerapan pendidikan karakter merupakan suatu kebutuhan yang tidak dapat ditawar-tawar lagi. Para putra-putri bangsa telah mengharumkan nama Indonesia di kancah internasional melalui prestasi-prestasi di berbagai bidang. Namun di sisi lain, kasus yang melibatkan mahasiswa sebagai pelaku tindak kejahatan dan kriminalitas cukup tinggi, seperti narkoba, dan seks bebas. Realitas mencengangkan tersebut merupakan 'tamparan keras' bagi bangsa.

Fenomena tersebut tentunya menuntut agar sistem pendidikan di kaji ulang. Dalam hal ini, kurikulum sebagai standar pedoman belum sepenuhnya merepresentasikan tujuan utama pendidikan itu sendiri, yaitu membentuk generasi cerdas komprehensif. Oleh karena itu, diperlukan reformasi pendidikan, demi memulihkan kesenjangan antara kualitas intelektual dengan nilai-nilai moral etika, budaya dan karakter.

Proses pendidikan di samping sebagai transfer pengetahuan seharusnya menjadi alat transformasi nilai-niali moral dan pembangunan karakter (character building). Semakin terdidik seseorang, secara logis, seharusnya semakin tahu mana jalan yang benar dan mana jalan yang menyimpang, sehingga ilmu dan kualitas akademis yang didapatkan tidak disalahgunakan.

Pendidikan karakter berupaya menjawab berbagai persoalan pendidikan dewasa ini. Pendidikan tersebut adalah sebuah konsep pendidikan yang integratif yang tidak hanya bertumpu pada pengembangan kompetensi kognitif peserta didik semata, tetapi juga pada penanaman nilai etika, moral dan spiritual.

Dalam rangka mewujudkan pendidikan karakter, tidaklah perlu dibuat mata kuliah baru, tetapi cukup diintegrasikan dalam pembelajaran pada setiap mata kuliah, termasuk di dalamnya bahasa Indonesia yang diajarkan di perguruan tinggi sebagai Mata Kuliah Umum (MKU) dan Mata Kuliah Pengembangan Kepribadian (MPK).

Mengkahiri pendahuluan ini, penulis ingin menyampaikan bahwa makalah ini disusun untuk menindaklanjuti rekomendasi yang disampaikan pada Kongres Bahasa 
Indonesia $\mathrm{X}$ terkait urgensi untuk melakukan peninjauan kembali terhadap kurikulum bahasa Indonesia di perguruan tinggi. Serta pengembangan lebih lanjut materi Kesusastraan, termasuk di dalamnya penulisan cerpen dan novel sebagai bagian dari materi ajar bahasa Indonesia di PT. Hal ini didasarkan atas pertimbangan bahwa materi ini sangat kaya untuk pengembangan atas nilai-nilai karakter, dan eksplorasi cara pengajaran kepada peserta didik. (Rabiah, 2013)

\section{B. Posisi Bahasa Indonesia di Perguruan Tinggi}

Pengajaran bahasa Indonesia di perguruan tinggi menempati posisi sebagai mata kuliah umum (MKU). Sebagaimana peran bahasa Indonesia sehari-hari sebagai alat komunikasi, dalam proses pengajarannya di perguruan tinggi bahasa Indonesia juga memegang peranan sentral sebagai sarana untuk aktualisasi diri mahasiswa, salah satunya melalui penulisan karya ilmiah.

Posisi ini semakin dikuatkan melalui SK Dirjen DIKTI No. 43/DIKTI/Kep/2006 tentang Rambu-Rambu Pelaksanaan Kelompok Mata Kuliah Pengembangan Kepribadian di Perguruan Tinggi. Dalam SK ini ditetapkan bahwa bahasa Indonesia digolongkan ke dalam kelompok Mata Kuliah Pengembangan Kepribadian (MPK).

Lebih lanjut kompetensi dasar MPK bahasa Indonesia sebagai berikut: menjadi ilmuwan dan profesional yang memiliki pengetahuan dan sikap positif terhadap bahasa Indonesia sebagai bahasa negara dan bahasa nasional dan mampu menggunakannya secara baik dan benar untuk mengungkapkan pemahaman, rasa kebangsaan dan cinta tanah air, dan untuk berbagai keperluan dalam bidang ilmu. teknologi dan seni, serta profesinya masing-masing.

Sedangkan substansi kajian untuk bahasa Indonesia mencakup butir-butir berikut: (a) mata kuliah bahasa Indonesia sebagai MPK menekankan keterampilan menggunakan bahasa Indonesia sebagai bahasa negara dan bahasa nasional secara baik dan benar untuk menguasai, menerapkan, dan mengembangkan ilmu pengetahuan. teknologi, dan seni sebagai perwujudan kecintaan dan kebanggaan terhadap bahasa Indonesia; (b) substansi kajian yang disebut pada butir (c) di bawah ini hendaknya dipadukan ke dalam kegiatan penggunaan bahasa Indonesia melalui keterampilan berbahasa menyimak, berbicara, membaca. dan menulis dengan keterampilan menulis akademik sebagai fokus.

Selanjutnya, (c) substansi kajian mata kuliah bahasa Indonesia difokuskan pada menulis akademik. Secara umurn. struktur kajian terdiri atas: (1) kedudukan Bahasa Indonesia: (a) sejarah bahasa Indonesia, (b) bahasa negara, (c) bahasa persatuan, (d) bahasa ilmu pengetahuan, teknologi. dan seni, dan (e) fungsi dan peran bahasa Indonesia dalam pembangunan bangsa; (2) menulis: (a) makalah, (b) rangkuman/ringkasan buku atau bab, dan (d) resensi buku; (3) membaca untuk menulis: (a) membaca tulisan/artikel ilmiah, (b) membaca tulisan populer, dan (c) mengakses informasi melalui internet; dan (3) berbicara untuk keperluan akademik: (a) presentasi, (b) berseminar, dan (c) berpidato dalam situasi formal. 
Dari substansi kajian untuk bahasa Indonesia di atas, kemudian diterjemahkan ke dalam standarisasi pengajaran bahasa Indonesia di perguruan tinggi dengan turunan materi sebagai berikut: (1) sejarah perkembangan bahasa Indonesia, (2) ejaan yang disempurnakan (EYD), (3) penulisan unsur serapan, (4) pemilihan kata, dan pengembangan kosa kata, dan tanda baca, (5) penyusunan kalimat, (6) pembentukan paragraf dan pengembangannya, (7) kutipan, (8) penyusunan catatan kaki, (9) daftar pustaka, (10) penyusunan karya ilmiah, dan laporan, serta (11) reproduksi dan resensi. (Mengacu pada Kurikulum Tingkat Satuan Pendidikan)

Berdasarkan paparan di atas, diketahui bahwa posisi bahasa Indonesia sebagai MKU dan MPK sangat strategis dan menyentuh seluruh lapisan mahasiswa di perguruan tinggi. Sehingga dapat dioptimalkan untuk menanamkan nilai-nilai karakter pada peserta didik. Namun demikian, jika dipelajari lebih lanjut, substansi kajian dari DIKTI dan materi bahasa Indonesia yang telah distandarisasi dan mengacu pada KTSP masih didominasi pembelajaran bahasa yang bersifat teknis.

\section{Pembelajaran Sastra dan Pendidikan Karakter}

Pembelajaran Sastra

Secara harfiah, Sastra (Sanskerta: shastra) merupakan kata serapan dari bahasa Sanskerta 'Sastra', yang berarti "teks yang mengandung instruksi" atau "pedoman", dari kata dasar 'Sas' yang berarti "instruksi" atau "ajaran" dan 'Tra' yang berarti "alat" atau "sarana". Sastra bisa juga dikenal dengan istilah Kesuastraan. Sedangkan beberapa ahli mendefinisikan Sastra sebagai berikut:

Semi (1988:8) menyatakan bahwa sastra adalah suatu bentuk dan hasil pekerjaan seni kreatif yang objeknya adalah manusia dan kehidupannya menggunakan bahasa sebagai mediumnya. Lalu, Esten (1978:9) mengemukakan bahwa sastra atau kesusastraan adalah pengungkapan dari fakta artistik dan imajinatif sebagai manifestasi kehidupan manusia. (dan masyarakat) melalui bahasa sebagai medium dan memiliki efek yang positif terhadap kehidupan manusia (kemanusiaan). Sedangkan, Sudjiman (1986 : 68) mengungkapkan bahwa sastra sebagai karya lisan atau tulisan yang memiliki berbagai ciri keunggulan seperti keorisinalan, keartistikan, keindahan dalam isi, dan ungkapanya.

Pendapat para ahli di atas masih mendefinisikan Sastra sebagai sesuatu yang abstrak, sedangkan pendapat dari Panuti sudah menekankan pembagian karya sastra. Oleh karena itu, pada bagian ini penulis menekankan bahwa Sastra yang akan diterapkan dalam pembelajaran merupakan hal yang berkenaan dengan kategori Sastra seperti: novel, cerita/cerpen (tertulis/lisan), syair, pantun, maupun sandiwara/drama.

Selanjutnya, penulis akan membahas tentang pembelajaran. Gagne (dalam Pribadi, 2009:9) mendefinisikan istilah pembelajaran sebagai serangkaian aktivitas yang sengaja diciptakan dengan maksud untuk memudahkan terjadinya proses belajar. Definisi lain tentang pembelajaran dikemukakan oleh Smith dan Ragan (1993:12) dalam Pribadi (2009:9) yang mendefinisikan bahwa pembelajaran adalah pengembangan dan 
penyampaian informasi dan kegiatan yang diciptakan untuk memfasilitasi pencapaian tujuan yang spesifik.

Miarso (2005:144) dalam Pribadi (2009:9) memaknai istilah pembelajaran sebagai aktivitas atau kegiatan yang berfokus pada kondisi dan kepentingan pembelajar (learner centered). Sedangkan Dick dan Carey (2005:205) dalam Pribadi (2009:9) mendefinisikan pembelajaran sebagai rangkaian peristiwa atau kegiatan yang disampaikan secara terstruktur dan terencana dengan menggunakan sebuah atau beberapa jenis media. Proses pembelajaran dalam hal ini bertujuan agar peserta didik dapat mencapai kompetensi seperti yang diharapkan. Untuk mencapai tujuan tersebut proses pembelajaran perlu dirancang secara sistematik dan sistemik.

Dari paparan di atas maka dapat disimpulkan bahwa pembelajaran sastra merupakan serangkaian peristiwa/aktivitas yang disampaikan secara terstruktur untuk mencapai kompetensi peserta didik melalui media novel, cerita/cerpen (tertulis/lisan), syair, pantun, maupun sandiwara/drama. Penerapan pembelajaran sastra akan dibahas pada bagian lainnya.

Konsep Pendidikan Karakter

Istilah karakter diambil dari bahasa Yunani yaitu 'to mark' yang artinya menandai. Istilah ini lebih fokus pada tindakan atau tingkah laku. Ada dua pengertian tentang karakter. Pertama, karakter menunjukkan bagaimana seseorang bertingkah laku. Apabila seseorang berperilaku tidak jujur, kejam, ataupun rakus tentulah orang tersebut dianggap memiliki perilaku buruk. Sebaliknya, apabila seseorang berperilaku jujur, suka menolong, tentulah orang tersebut dianggap memiliki karakter mulia. Kedua, istilah karakter erat kaitannya dengan 'personality'. Seseorang baru bisa disebut 'orang yang berkarakter', apabila tingkah lakunya sesuai kaidah moral. Imam Ghozali menganggap bahwa karakter lebih dekat dengan akhlak, yaitu spontanitas manusia dalam bersikap atau melakukan perbuatan yang telah menyatu dalam dirinya. (Kemendikbud, 2011:910)

Sedangkan pendidikan merupakan proses internalisasi budaya ke dalam diri seseorang dan masyarakat sehingga membuat orang dan masyarakat menjadi beradab. Pendidikan bukan merupakan sarana transfer ilmu pengetahuan saja, tetapi lebih luas lagi pendidikan merupakan saran pembudayaan dan penyaluran nilai (enkulturasi dan sosialisasi). (Kemendikbud, 2011:13)

Dari pengertian di atas, maka dapat disimpulkan bahwa pendidikan karakter merujuk pada upaya menjadikan peserta didik (mahasiswa) menjadi beradab disertai upaya membina peserta didik agar memiliki karakter mulia, maupun sesuai kaidah moral. 
Nilai-Nilai Karakter dalam Pembelajaran Sastra

Saryono (2009:52-186) mengemukakan bahwa genre sastra yang dapat dijadikan sarana untuk membentuk karakter bangsa, antara lain, genre sastra yang mengandung nilai atau aspek (1) literer-estetis, (2) humanistis, (3) etis dan moral, dan (4) religiussufistis-profetis. Keempat nilai sastra tersebut dipandang mampu mengoptimalkan peran sastra dalam pembentukan karakter bangsa.

Genre sastra yang mengandung nilai literer-estetis adalah genre sastra yang mengandung nilai keindahan, keelokan, kebagusan, kenikmatan, dan keterpanaan yang dimungkinkan oleh segala unsure yang terdapat di dalam karya sastra. Karya sastra klasik atau karya sastra yang menjadi sastra kanon (belle lettres) mengandung nilai literer-estetis.

Genre sastra yang mengandung nilai humanistis adalah genre sastra yang mengandung nilai kemanusiaan, menjunjung harkat dan martabat manusia, serta menggambarkan situasi dan kondisi manusia dalam menghadapi berbagai masalah. Kehadiran karya sastra semacam itu diharapkan dapat membentuk kearifan budaya bangsa Indonesia yang memiliki rasa perikemanusiaan yang adil, beradab, dan bermartabat.

Genre sastra yang mengandung nilai etis dan moral dalam karya sastra mengacu pada pengalaman manusia dalam bersikap dan bertindak, melaksanakan yang benar dan yang salah, serta bagaimana seharusnya kewajiban dan tanggung jawab manusia dilakukan. Sudah sejak dahulu karya sastra diperlakukan sebagai wahana penyimpan dan perawat nilai etis dan moral.

Sastra religius-sufistis-profetis adalah genre sastra yang menyajikan pengalaman spiritual dan transendental. Genre sastra ini telah lama ada, bahkan Mangunwijaya (1982) menyatakan bahwa pada awalnya semua karya sastra adalah religius. Semua sastra pada awalnya digunakan sebagai sarana berpikir dan berzikir manusia akan kekuasaan, keagungan, kebijaksanaan,dan keadilan Tuhan yang Maha Esa. Kerinduan manusia kepada Tuhan, bahkan hubungan kedekatan manusia dengan Tuhan, telah lama ditulis dalam karya sastra para sufi, seperti Hamzah Fansuri, Nuruddin Ar Raniri, Al Halaj, Amir Hamzah, Abdul Hadi W.M., Sutardji Calzoum Bachri, dan Danarto.

Optimalisasi nilai-nilai karakter yang telah berhasil teridentifikasi di atas sangat ditentukan oleh kemauan apresiator (peserta didik dan dosen) dalam mengapresiasi sastra dalam bentuk membaca dan mengaplikasikannya dalam kehidupan sehari-hari.

\section{Integrasi Nilai-Nilai Karakter melalui Pembelajaran Sastra dalam Mata Kuliah Bahasa Indonesia di Perguruan Tinggi}

Pembelajaran Sastra dalam Mata Kuliah Bahasa Indonesia di Perguruan Tinggi

Sebagaimana telah dipaparkan di awal bahwa pembelajaran sastra merupakan serangkaian peristiwa/aktivitas yang disampaikan secara terstruktur untuk mencapai kompetensi peserta didik melalui media novel, cerita/cerpen (tertulis/lisan), syair, 
pantun, maupun sandiwara/drama. Jika dihubungkan dengan posisi bahasa Indonesia di perguruan tinggi, maka substansi kajian yang diinginkan yakni terpenuhinya keterampilan berbahasa yakni menyimak, menulis, membaca dan berbicara yang ditekankan pada menulis akademik.

Walaupun, sastra tidak bisa dikelompokkan ke dalam aspek keterampilan berbahasa karena bukan bidang yang sejenis. Namun, pembelajarannya dapat dilaksanakan secara terintegrasi dengan pembelajaran bahasa, baik dengan keterampilan menyimak, menulis, membaca maupun berbicara. Hasil integrasi ini tentunya sejalan dengan substansi MPK bahasa Indonesia di perguruan tinggi.

Dalam prakteknya keterampilan tersebut dapat diintegrasikan sebagai berikut: (1) menyimak sastra: mendengarkan dan merefleksikan pembacaan puisi, dongeng, cerpen, novel, pementasan drama; (2) menulis sastra: menulis puisi, menulis cerpen, menulis novel, menulis drama; (3) membaca sastra: membaca karya sastra dan memahami maknanya, baik terhadap karya sastra yang berbentuk puisi, prosa, maupun naskah drama; dan (4) berbicara sastra: berbalas pantun, deklamasi, mendongeng, bermain peran berdasarkan naskah, menceritakan kembali isi karya sastra, menanggapi secara lisan pementasan karya sastra.

Lebih lanjut sasaran pembelajaran dari tiap keterampilan berbahasa yang diintegrasikan dengan pemahaman sastra antara lain sebagai berikut: (1) menyimak sastra ditujukan untuk mengembangkan kemampuan dalam memahami pikiran, perasaan, dan imajinasi yang terkandung dalam karya sastra yang dilisankan; (2) menulis sastra ditujukan agar peserta didik menguasai teori penulisan sastra yang berkaitan dengan unsur-unsur dan kaidah-kaidah dalam penulisan sastra, teknik penulisan sastra, dan estetika serta terampil menulis sastra; (2) membaca sastra ditujukan agar peserta didik mampu mengembangkan kompetensi yang berkaitan dengan hakikat membaca, hakikat sastra dan membaca sastra, teknik memahami dan mengomentari karya sastra; dan (4) berbicara sastra ditujukan untuk menguasai ekspresi sastra dalam berbagai jenis dan bentuk.

Integrasi Nilai-Nilai Karakter melalui Pembelajaran Sastra

Terkait dengan nilai-nilai karakter, Kementerian Pendidikan mengidentifikasi 18 nilai yang bersumber dari agama, Pancasila, budaya dan tujuan pendidikan nasional yang ditawarkan sebagai rumusan dasar bagi setiap jenis dan jenjang pendidikan untuk dimasukkan ke dalam kurikulum, yaitu: (1) Religius, (2) Jujur, (3) Toleransi, (4) Disiplin, (5) Kerja keras, (6) Kreatif, (7) Mandiri, (8) Demokratis, (9) Rasa Ingin Tahu, (10) Semangat Kebangsaan, (11) Cinta Tanah Air, (12) Menghargai Prestasi, (13) Bersahabat/Komunikatif, (14) Cinta Damai, (15) Gemar Membaca, (16) Peduli Lingkungan, (17) Peduli Sosial dan (18) Tanggung jawab (Pusat Kurikulum, 2009:9-10 dalam Kemdikbud Dirjen Pendidikan Dasar, 2011:26-27).

Sedangkan Saryono (2009:52-186) secara spesifik mengemukakan 4 genre sastra yang dapat dijadikan sarana untuk membentuk karakter bangsa, yakni (1) literer-estetis yang mengandung nilai keindahan, keelokan, kebagusan, kenikmatan, dan keterpanaan 
(terdapat dalam karya sastra klasik); (2) humanistis yang mengandung nilai kemanusiaan, menjunjung harkat dan martabat manusia, serta menggambarkan situasi dan kondisi manusia dalam menghadapi berbagai masalah; (3) etis dan moral yang mengacu pada pengalaman manusia dalam bersikap dan bertindak, melaksanakan yang benar dan yang salah, serta bagaimana seharusnya kewajiban dan tanggung jawab manusia dilakukan; dan (4) religius-sufistis-profetis menyajikan pengalaman spiritual dan transendental.

Integrasi nilai-nilai karakter pada pembelajaran menuntut keterampilan dalam merumuskannya. Terkait hal ini, Kemdikbud (2011:13) memberikan masukan terkait cara-cara yang dapat ditempuh, antara lain sebagai berikut: (1) mengungkapkan nilainilai yang ada dalam materi pembelajaran, (2) mengintegrasikan nilai-nilai karakter menjadi bagian terpadu dari materi pembelajaran, (3) menggunakan perumpamaan, dan membuat perbandingan dengan kejadian serupa dalam hidup peserta didik (mahasiswa), (4) mengubah hal-hal negatif menjadi nilai positif, (5) mengungkapkan nilai-nilai melalui diskusi dan brainstorming, (6) menggunakan cerita untuk memunculkan nilainilai, (7) menceritakan kisah hidup orang-orang besar, (8) mengenalkan tokoh yang ada dalam kitab suci, (9) menggunakan drama untuk melukiskan kejadian-kejadian yang berisi nilai-nilai, dan (10) menggunakan berbagai kegiatan, seperti kegiatan amal, dan bakti sosial, maupun (11) praktik lapangan seperti kelompok belajar tematik antarmahasiswa. Berikut dipaparkan penerapannya dalam pembelajaran sastra.

\section{a. Cerpen}

Pembelajaran sastra melalui cerpen bisa melibatkan cara (3) dan (4) yakni membuat perbandingan dengan kejadian serupa dalam hidup peserta didik serta mengubah hal-hal negatif menjadi nilai positif. Teknisnya dosen meminta mahasiswa untuk menuliskan cerita pendek, kemudian mengambil perwakilan dari mahasiswa tersebut untuk membaca dan memperdengarkannya di depan kelas. Dari aktivitas ini, mahasiswa yang lainnya bisa melakukan introspeksi pada diri sendiri. Ketika proses ini telah berjalan, dosen juga dapat memberikan masukan kepada mahasiswa yang telah membacakan cerpennya tersebut.

\section{b. Puisi (lagu)}

Pembelajaran sastra melalui puisi bisa melibatkan cara (1) yakni mengungkapkan nilai yang ada dalam pembelajaran. Teknisnya dosen dapat mempersiapkan sendiri maupun menugaskan persiapannya kepada mahasiswa yakni beberapa contoh puisi maupun lagu-lagu dan musik. Puisi yang telah dipersiapkan dibacakan oleh mahasiswa, kemudian dari puisi tersebut diungkapkan nilai karakter yang terkandung didalamnya. Apabila berbentuk lagu/musik dapat diperdengarkan kepada mahasiswa dan mereka diminta untuk memberikan tanggapan terhadap nilai karakter yang terungkap dari lagu/musik tersebut.

c. Drama 
Pembelajaran sastra melalui drama telah diungkapkan secara eksplisit pada cara (9). Diterangkan bahwa, drama dapat digunakan untuk melukiskan kejadian-kejadian yang berisi nilai-nilai. Melalui pementasan drama, peserta didik diharapkan dapat mengikuti tahapannya yakni: menyusun naskah drama hingga mementaskannya di depan kelas. Dari proses ini diharapkan peserta didik mampu memahami dan menyerap nilai-nilai karakter yang terkandung dalam drama yang dibawakan oleh kelompok sendiri, maupun drama yang dipentaskan oleh kelompok lain.

\section{d. Novel}

Pembelajaran sastra melalui novel bisa melibatkan cara (5) yakni mengungkapkan nilainilai melalui diskusi dan brainstorming. Teknisnya, dosen menentukan tema-tema Novel yang dianggap merepresentasikan nilai karakter, kemudian mahasiswa diminta untuk mencari Novel yang dimaksud. Selanjutnya, novel tersebut didiskusikan perkelompok diarahkan oleh dosen. Kemudian hasil diskusi kemudian dipresentasikan di depan kelas, dimana kelompok lainnya menyimak temuan dari kelompok yang presentasi. Dengan demikian nilai-nilai karakter dalam beberapa novel dapat diserap oleh mahasiswa yang terlibat di dalam kelas.

\section{e. Pantun}

Pembelajaran sastra melalui pantun bisa melibatkan cara (1) dan (3) yakni mengungkapkan nilai karakter yang ada dalam pembelajaran serta membandingkannya dengan kehidupan sehari-hari peserta didik. Teknisnya, dosen menugaskan mahasiswa untuk membuat berbagai pantun, misalnya pantun nasehat untuk memunculkan berbagai karakter dalam kehidupan mahasiswa. Nasehat-nasehat yang dibuat akan membekas diingatannya serta besar kemungkinan akan diaplikasikan dalam kehidupannya karena nasehat itu berasal dari dirinya untuk teman-temannya, dan begitupun sebaliknya.

\section{f. Cerita Lisan}

Pembelajaran sastra melalui cerita lisan bisa melibatkan cara (6), (7), dan (8) yakni menggunakan cerita untuk memunculkan nilai-nilai, adapun nilai-nilai tersebut berasal dari kisah hidup orang-orang besar maupun mengenalkan tokoh dari kitab suci. Teknisnya, dosen dapat menugaskan mahasiswa untuk mencari cerita yang berkaitan dengan tokoh inspiratif dari masing-masing mahasiswa. Setelah itu, mahasiswa diminta untuk menceritakan kembali di depan kelas. Hal ini tentunya akan berdampak kepada pribadi mahasiswanya maupun sejawatnya di kelas. Dari cerita yang telah dipresentasikan, setiap mahasiswa bisa diambil keteladanan dari tokoh-tokoh tersebut. Selain menceritakan tokoh-tokoh, cerita/sastra lisan ini juga sangat erat kaitannya dengan cerita rakyat. Sehingga cerita rakyat yang berasal dari daerah mahasiswa tersebut dapat dipelajari juga oleh mahasiswa yang berasal dari daerah yang berbeda.

Walaupun penjelasan di atas banyak menitikberatkan pada penugasan mahasiswa. Namun peran dosen tetap diperlukan untuk menyeleksi bahan yang akan dipresentasikan oleh mahasiswa. Dengan pemilihan bahan yang tepat, peserta didik 
akan merasakan kedalaman materi yang membuat mereka menyadari makna kehidupan. Kesadaran itulah yang membuat mereka menyadari makna kehidupan. Kesadaran itu juga yang akan membuat pembelajaran bukan sekedar mengajarkan materi, tetapi juga mendidik dengan nilai-nilai karakter yang terkandung dalam setiap materi yang disampaikan.

\section{E. Penutup}

Kesimpulan

Berdasarkan pemaparan di atas, maka dapat disimpulkan bahwa penanaman nilai-nilai karakter melalui pembelajaran sastra dalam mata kuliah bahasa Indonesia di perguruan tinggi sangat dimungkinkan untuk direalisasikan. Setelah melakukan telaah terhadap SK DIKTI No. 43/DIKTI/Kep/2006 yang menjadi pondasi bahasa Indonesia di perguruan tinggi sebagai MPK sekaligus MKU. Dari aturan tersebut ditemukan bahwa pada substansi kajian dimungkinkan bagi pembelajaran sastra untuk terintegrasi didalamnya sebagai bagian dari keterampilan berbahasa (menyimak, menulis, membaca dan berbicara).

Lebih lanjut diungkapkan juga bahwa pada setiap kategori sastra yang dikembangkan terdapat juga cara-cara pengungkapan nilai-nilai karakter yang dianjurkan oleh DIKTI. Salah satunya, seperti penggunaan drama untuk melukiskan kejadian-kejadian yang berisi nilai-nilai. Adapun nilai-nilai karakter yang ingin dikembangkan dalam pembelajaran dapat mengacu pada 18 nilai karakter oleh Kemdikbud, maupun 4 genre sastra yang dapat membentuk karakter bangsa oleh Saryono.

\section{Rekomendasi}

Penulis mengajak segenap dosen Bahasa dan Sastra Indonesia se-Indonesia maupun pengembang materi ajar bahasa Indonesia untuk perguruan tinggi agar mempertimbangkan untuk memasukkan pembelajaran sastra ke dalam mata kuliah bahasa Indonesia. Utamanya bagi pengajaran bahasa Indonesia di luar Prodi. Bahasa dan Sastra Indonesia. Hal ini dimaksudkan agar mata kuliah ini bisa memberikan tempat bagi mahasiswa menggali dan mengaktualisasikan potensi dirinya melalui bahasa dan sastra.

\section{REFERENCES}

-----------. Surat Keputusan Direktorat Jenderal Pendidikan Tinggi No. 43/DIKTI/Kep/2006. http://luk.staff.ugm.ac.id/atur/SKDirjen43-DIKTI-Kep-2006.pdf (diakses 25 September 2014)

Asmani, Jamal Ma'mur. 2011. Buku Panduan Internalisasi Pendidikan Karakter di Sekolah. Yogyakarta: Diva Press. 
Barnawi dan M. Arifin. 2012. Strategi dan Kebijakan Pembelajaran Pendidikan Karakter. Yogyakarta: Ar-Ruzz Media.

Esten, Mursal. 1978. Kesusasteraan: Pengantar Teori dan Sejarah. Bandung : Angkasa.

Fananie, Zainuddin. 2002. Telaah Sastra. Surakarta: Muhammadiyah University Press.

Kementerian Pendidikan dan Kebudayaan. 2011. Pembelajaran Kontekstual dalam Membangun Karakter Siswa. Jakarta: Kemendikbud.

Noor, Rohinah M. 2011. Pendidikan Karakter Berbasis Sastra: Solusi Pendidikan Moral yang Efektif. Yogyakarta: Ar-Ruzz Media.

Pribadi, Benny A. 2010. Model Desain Sistem Pembelajaran. Jakarta: Dian Rakyat.

Rabiah, Sitti. 2013. Bahasa Indonesia di Perguruan Tinggi sebagai Wahana Pembangun Karakter (Jati Diri) dan Kreatifitas Mahasiswa: Studi Kasus di Universitas Muslim Indonesia, Makassar. Disajikan pada Kongres Bahasa Indonesia X oleh Badan Bahasa di Jakarta 28-31 Oktober 2013. doi: 10.31227/osf.io/mqe8y .

Samosir, Aldon. Pembelajaran Sastra.

http://aldonsamosir.wordpress.com/kurikulum/pembelajaran-sastra/ (diakses 25

September 2014)

Saryono, Djoko. 2009. Dasar Apresiasi Sastra. Yogyakarta: Elmatera Publishing.

Semi, M. Atar. 1988. Anatomi Sastra. Padang: Angkasa Raya.

Septiningsih, Lustantini. Mengoptimalkan Peran Sastra dalam Pembentukan Karakter Bangsa. http://badanbahasa.kemdikbud.go.id/lamanbahasa/content/mengoptimalkanperan-sastra-dalam-pembentukan-karakter-bangsa (diakses 25 September 2014)

Sudjiman, Panuti. 1986. Kamus Istilah Sastra. Jakarta: Gramedia. 